\title{
Phylogeny of Elatostema (Urticaceae) using chloroplast DNA data
}

\author{
Julisasi T. Hadiah, Christopher J. Quinn and Barry J. Conn
}

\begin{abstract}
Hadiah, Julisasi T.1,2, Christopher J. Quinn ${ }^{2}$ and Barry J. Conn ${ }^{2}\left({ }^{1}\right.$ School of Biological, Earth and Environmental Sciences, University of New South Wales, Sydney, NSW 2052, Australia; ${ }^{2}$ Royal Botanic Gardens Sydney, Mrs Macquaries Road, Sydney, NSW 2000, Australia) 2003. Phylogeny of Elatostema (Urticaceae) using chloroplast DNA data. Telopea 10(1) 235-246. Phylogenetic analyses of the Urticales, based on chloroplast DNA data, support the monophyly of the Urticaceae, Boehmeria, Pilea and Procris, but not of Elatostema. Our result suggests that the circumscription of Procris is to be extended or included within Elatostema. At the tribal level, both Boehmerieae and Lecantheae appear paraphyletic, although this may be an artefact of the low taxon sampling. Preliminary analyses of relationships within Elatostema do not support the recognition of the subgenus Pellionia.
\end{abstract}

\section{Introduction}

Friis (1989 \& 1993) provides a detailed comparison of morphological features of the Urticaceae at the familial, infrafamilial, and generic levels with a brief discussion of higher-level relationships based on previous classical taxonomic approaches. Recent phylogenetic studies involving the Urticaceae have concentrated on ordinal relationships. The circumscription of the Urticales has been relatively stable since the mid 1800s when Weddell (1856) included Artocarpeae, Cannabineae, Moreae, Ulmaceae and Urticaceae in the order. This classification was used by Thorne (1992) and Takhtajan (1997). Barbeyaceae was added by Dickison and Sweitzer (1970) and followed by Cronquist (1981), Dahlgren (1989), and Friis (1993). Cecropiaceae was proposed by Berg (1978) and placed close to Moraceae and Urticaceae. The reconstructed high-level phylogenies of Chase et al. (1993), using the DNA sequences of the chloroplast gene $r b c \mathrm{~L}$, support the monophyly of the Urticales with Cannabaceae, Moraceae, Ulmaceae and Urticaceae included. However, subsequent analyses including additional loci (Angiosperm Phylogeny Group 1998; Soltis et al. 2000) and non-molecular data (Judd et al. 1999) have shown this group to be nested within the Rosales. All these authors consider Cannabaceae, Celtidaceae, Cecropiaceae, Moraceae and Ulmaceae to be the closest families to Urticaceae.

Weddell $(1854,1856,1869)$ revised the familial and infrafamilial classification of Urticaceae devised by Gaudichaud (1830) and recognised five tribes, namely, Lecantheae, Urereae (= Urticeae sensu Friis 1989), Boehmerieae, Parietarieae and Forskohleae (= Forsskaoleae sensu Friis 1989), renaming the tribe Lecantheae to Procrideae (Weddell 1856). Friis (1993) accepted Weddell's circumscription of these five tribes; however, he reversed the name Procrideae to Lecantheae (as accepted here). Friis $(1989,1993)$ characterised the Lecantheae as having staminodes that eject the mature achenes; leaves which are opposite, anisophyllous to completely reduced; intrapetiolar and fused stipules; and uniformly linear cystoliths. The Urticeae was characterised by the presence of stinging hairs. However, he questioned the distinctiveness of the other three tribes, and suggested further work may lead to a taxonomic rearrangement at the tribal level (Friis 1989). 
Phylogenetic reconstruction of the Urticaceae using morphological data (Beaman 2000, Fig. 3-3), as part of a study of Elatostema from Mt Kinabalu (Malaysia), provided support for the monophyly of Lecantheae and Urticeae, but suggested that the Boehmerieae is polyphyletic. The Lecantheae consists of seven genera (Friis 1993), including Elatostema, the focus of our study. The genus consists of approximately 300 herbaceous to shrubby species (Friis 1993) that are characterised by having the female flowers arranged on a flattened discoid or lobed receptacle.

Schröter and Winkler (1935) recognized four subgenera within Elatostema, namely Elatostema (as 'Euelatostema'), Elatostematoides, Pellionia and Weddelia, based on several features, but particularly the nature of leaves, stipules, inflorescence, and presence and form of the receptacle. Friis $(1989,1993)$ made no comment on the subgenera, but the analyses of Beaman $(2000,2001)$ did not support the arrangement.

This paper summarises the preliminary evaluation of different regions of the chloroplast genome for estimating relationships within Urticaceae, in general, and within Elatostema, in particular. As part of our continuing Urticaceae research program, we also aim to test the monophyly of the Lecantheae and Elatostema.

\section{Materials}

Plant materials used for the molecular work were either collected specifically for this project (namely from Indonesia - Sumatera, Java and Bali; and Australia - New South Wales, including Lord Howe Island) or are part of the horticultural collections at Royal Botanic Gardens Sydney. Fresh leaf material, particularly from the young shoots, cleaned and stored in airtight plastic bags with silica gel, was used for DNA analysis. These samples were stored at $-20^{\circ} \mathrm{C}$. The voucher specimens for DNA extracts are listed in Appendix 1 (all held at NSW).

\section{Methods}

Three regions of the chloroplast genome were selected for this study. The $r b c \mathrm{~L}$ gene was chosen to test the monophyly of the family because of the availability in GenBank of sequences for representatives of several of the related families. Two potentially more informative regions were chosen to examine relationships within the family: the $a t p ß-r b c \mathrm{~L}$ intergenic spacer and a region including the $t r n \mathrm{~L}$ intron, the $t r n \mathrm{~L}-\mathrm{F}$ intergenic spacer, and the intervening $\operatorname{trn} \mathrm{L}$ exon. For simplicity, the latter is henceforth referred to as trn.

DNA was extracted from $0.2-0.25 \mathrm{~g}$ silica gel dried leaves and purified using the protocol of Gilmore et al. (1993). The three regions were amplified by polymerase chain reaction (PCR) in an FTS-4000 Thermal Sequencer (Corbett Research, Mortlake NSW) using $20 \mu \mathrm{M}$ of the primers as listed in Appendix 2. All the PCR products were purified using CONCERT ${ }^{\text {TM }}$ Rapid PCR Purification System (protocol provided by manufacturer). The cleaned PCR products were auto-sequenced at SUPAMAC (Sydney University Prince Alfred Macromolecular Analysis Centre). The DNA sequences were edited and aligned using Sequencher 3.1.1. (Gene Codes Corp., Inc., Ann Arbor, Michigan) with subsequent manual adjustment. Sequences were then viewed in MacClade Version 4.03 (Maddison \& Maddison 2001) to assist with the positioning of segments affected by insertion/deletion mutations (indels). Deleted segments were treated as missing data in the analyses. 
Our data for $r b c \mathrm{~L}$ and $t r n$ were supplemented by sequences of the following taxa obtained from GenBank: Celtis sinensis (Ulmaceae), Dorstenia psilurus, Ficus pretoriae, Morus alba (2 accessions) and M. rubra (Moraceae), Cannabis sativa and Humulus lupulus (Cannabaceae) as indicated in Appendix 1. Since Chase et al. (1993, figs 11B \& 16) and Soltis et al. (2000, fig. 7) concluded that the Urticaceae, Cannabaceae, Moraceae and Ulmacaeae (Celtidaceae sensu Soltis et al.) form a strongly supported clade, species from the latter three families have been used for outgroup comparison in the $r b c \mathrm{~L}$ analysis. This analysis was used to test the monophyly of Urticaceae. Outgroup choice for each of the other two data sets was based on the $r b c \mathrm{~L}$ analysis, as set out below.

Heuristic searches were performed in PAUP* Version 4.0b10 (Swofford 2002) using tree bisection reconnection branch-swapping and the MULPARS option, with all characters equally weighted to find the most parsimonious trees. Analyses involved 100 replicates of random taxon addition in order to search for multiple islands of equally parsimonious trees. Branch lengths for trees were calculated using the ACCTRAN (accelerated transformation optimisation) option in PAUP. Relative support for the clades identified by parsimony analysis was estimated by jackknife with 10000 replicates of fast stepwise addition using 33\% character deletion and 'emulate jac resampling'.

\section{Results}

\section{The $r b c \mathrm{~L}$ database}

Sequences were generated for 9 ingroup taxa from the Urticaceae, and another two ingroup and seven outgroup sequences were added from GenBank. A total of 1346 aligned positions was included in the analyses, of which $226(16.8 \%)$ were variable and $140(10.4 \%)$ parsimony informative. Missing data constituted $6.5 \%$ of the database, the taxon with the most missing data being Ficus pretoriae (33\%). Initial heuristic analyses gave a topology that did not accord with the family level relationships and cast doubt on the identity of two of the outgroup sequences obtained from GenBank: Morus alba L01933 and Dorstenia psilurus. A BLAST search (NCBI November 2002) placed the former among a group of Prunus sequences (Rosaceae), and the latter among Rhamnaceae. A further outgroup sequence belonging to Prunus persica (Table 1) was obtained from GenBank and added to the data set, and the analysis repeated using the two Rosaceae sequences as root.

Heuristic search found a single island of two trees of 374 steps, consistency index (CI) $=0.606$ without uninformative characters, retention index $(\mathrm{RI})=0.708$, and rescaled consistency index $(\mathrm{RC})=0.496$. The strict consensus tree is shown in Figure 1 . The names of the misidentified taxa are shown within inverted commas. There is strong support (95\% jackknife) for a sister relationship between Urticaceae and the clade comprising Moraceae, Cannabaceae and Ulmaceae. The two sequences of each of Elatostema and Procris are strongly grouped (jackknife support $\geq 95 \%$ ), as are the four sequences of Boehmeria ( $94 \%$ support), and there is $82 \%$ support for the monophyly of Urticaceae. Pilea pumila is placed sister to Urtica dioica (89\% support) rather than with the other genera of the tribe Lecantheae, Elatostema and Procris. Myriocarpa longipes, of the Boehmerieae, is placed closer to all four of the above genera ( $80 \%$ support) than to the Boehmeria clade. 


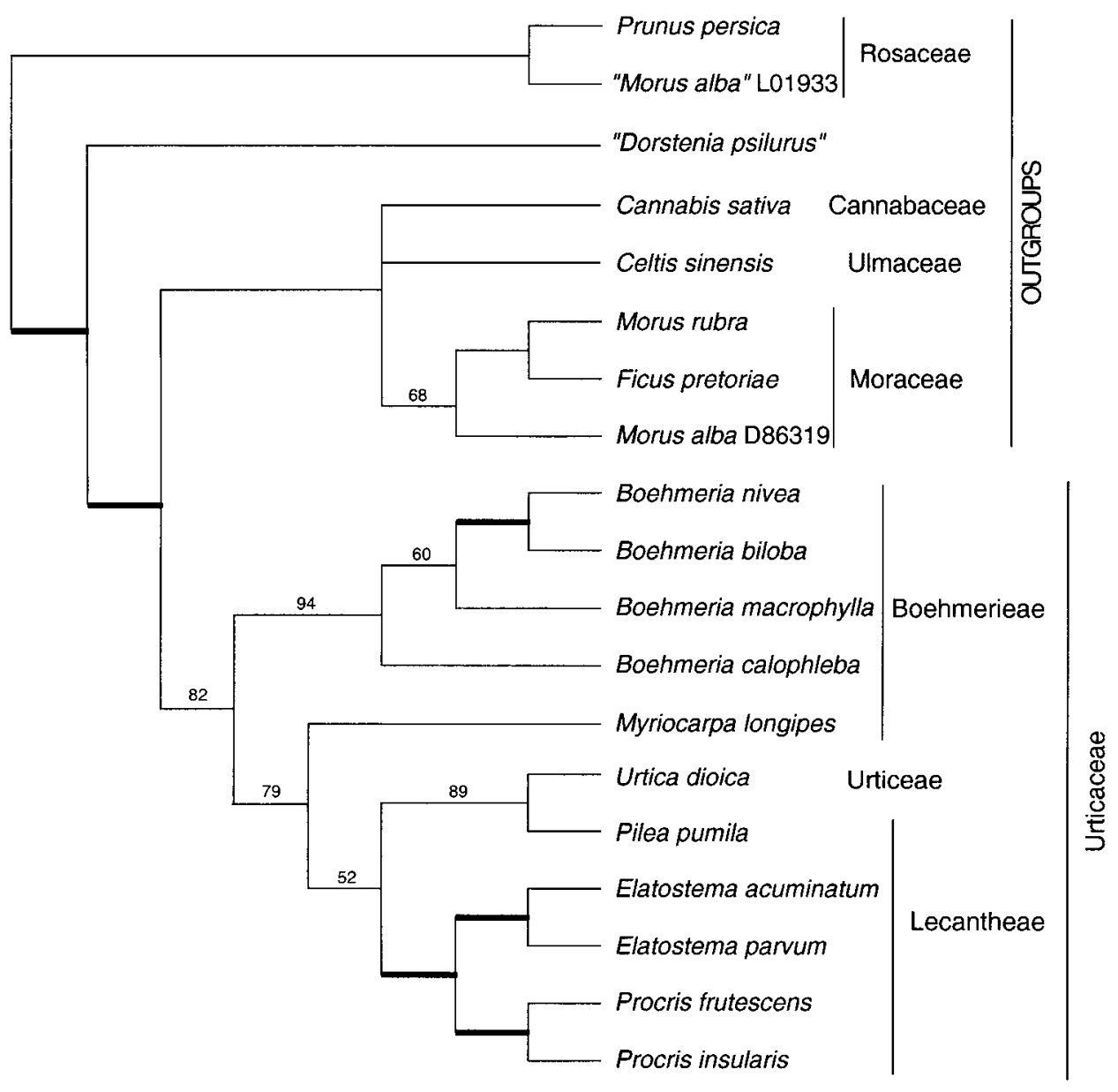

Fig. 1. Strict consensus of two equally parsimonious trees of 374 steps found from heuristic search of the $r b c \mathrm{~L}$ data. $\mathrm{CI}=0.606$ excluding uninformative characters; $\mathrm{RI}=0.708$; $\mathrm{RC}=0.496$. Thick branches received $>95 \%$ support; other jacknife values $>50 \%$ shown above the clades. 


\section{The $a t p ß-r b c \mathrm{~L}$ database}

Fourteen species of Urticaceae were sequenced, thirteen representing Lecantheae (Elatostema, Procris and Pilea), and Myriocarpa longipes from the Boehmerieae sensu Friis (1993). The latter was used to root the analysis. Alignment required numerous indels ranging from 1-69 bp. The aligned data constituted 962 positions. There were 168 variable positions $(17.5 \%)$, of which $84(8.7 \%)$ were potentially informative. Six potentially informative indels, ranging from 1-10 bp, were scored as additional characters (sequence present/absent) and added to the database. Missing data constituted $14.9 \%$ of the data set.

Heuristic search found a single island of ten trees of 191 steps, CI $=0.922$ excluding uninformative characters, $\mathrm{RI}=0.948, \mathrm{RC}=0.908$. The strict consensus of these trees is shown in Figure 2. The distributions of informative indels have been mapped on the tree. Both Elatostema and Procris are very strongly supported as monophyletic groups (100\% and three and two indels, respectively), and there is $95 \%$ support for a sister relationship between them.

\section{The trn database}

Sequences were generated for 24 taxa representing 16 species or species groups of Elatostema and eight other species of Urticaceae. Sequences of two outgroup species, namely Humulus lupulus and Cannabis sativa, were taken from GenBank. A total of 1108 aligned positions were included in the analyses, which included 582 base pairs (bp) of the $t r n \mathrm{~L}$ intron, $50 \mathrm{bp}$ of the $t r n \mathrm{~L}$ exon, and $449 \mathrm{bp}$ of the $t r n \mathrm{~L}-\mathrm{F}$ intergenic spacer (the last $4 \mathrm{bp}$ of the spacer were omitted). Alignment required numerous indels involving from 1-101 bp. Missing characters constituted $16.2 \%$ of data, with the taxon having the highest proportion of missing data being Cannabis sativa (39.6\%). Thirty-one potentially informative indels, ranging from 1-51 bp, were scored as sequence present or absent and added to the database. There were 431 (38.9\%) variable positions, 258 of which $(23.3 \%)$ were potentially informative.

Heuristic search found a single island of two equally parsimonious trees of 663 steps, $\mathrm{CI}=0.733$ excluding uninformative characters, $\mathrm{RI}=0.846, \mathrm{RC}=0.688$. The strict consensus of these trees is shown in Figure 3. The distributions of informative indels have been mapped on this cladogram (Fig. 3). The species pairs representing Boehmeria, Pilea and Procris are each strongly grouped (100\%), but Elatostema appears paraphyletic, with E. curtisii and E. repens placed sister to Procris with $99 \%$ support, whereas the remaining members of Elatostema constitute a very robust clade $(100 \%$ support). There is good support (91\%) for a sister relationship between these two clades. Once again, Urtica dioica is placed sister to Pilea, but jackknife support for this relationship is very weak (54\%).

\section{Discussion}

Friis (1993) provides a detailed discussion of morphological characters of the Urticaceae. He circumscribed the family as having basal ovaries and stamens that are elastic and reflexed (Friis 1989, 1993). However, he does not provide a phylogenetic interpretation of these data. The monophyly of the Urticaceae was tentatively supported by Beaman (2000), based on morphological characters.

The analysis of the $r b c \mathrm{~L}$ data, which places all Urticaceae within a clade that is sister to the five taxa belonging to three of the other five families of the order Urticales sensu Cronquist (1981), provides support for the concept of the family. The ingroup clade, which comprises 11 sequences drawn from six genera and three of the five tribes, receives $82 \%$ jackknife support. The current tribal arrangement, however, receives no 


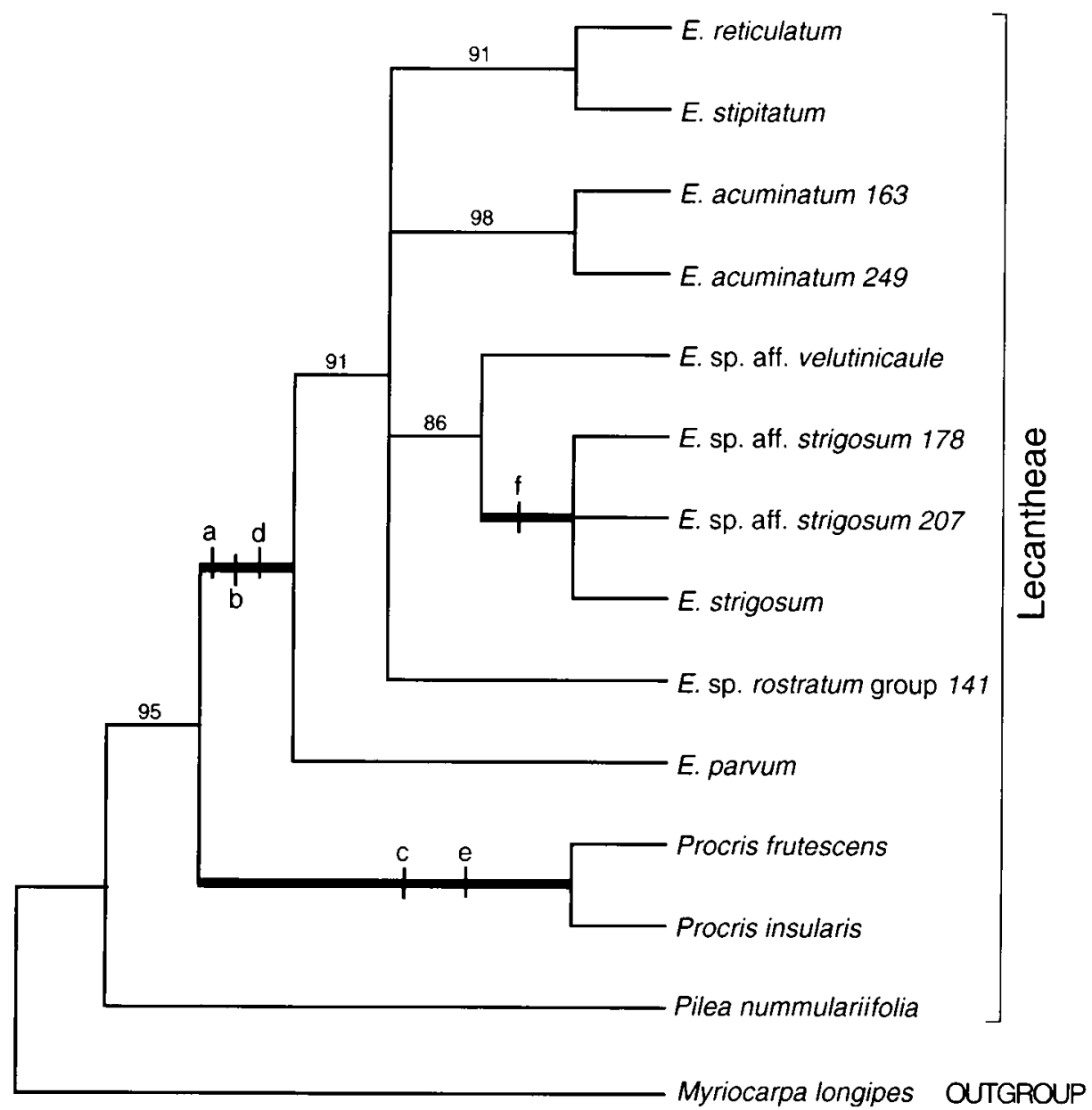

Fig. 2. Strict consensus of the 10 equally parsimonious trees of 191 steps found from heuristic search of the $a t p ß-r b c \mathrm{~L}$ spacer data set; $\mathrm{CI}=0.922$ excluding uninformative characters; $\mathrm{RI}=0.948$; $\mathrm{RC}=0.908$. Thick branches received $100 \%$ jackknife support; other values $>50 \%$ shown above the branches. Distributions of indels a-f are mapped on the tree. E., Elatostema. 


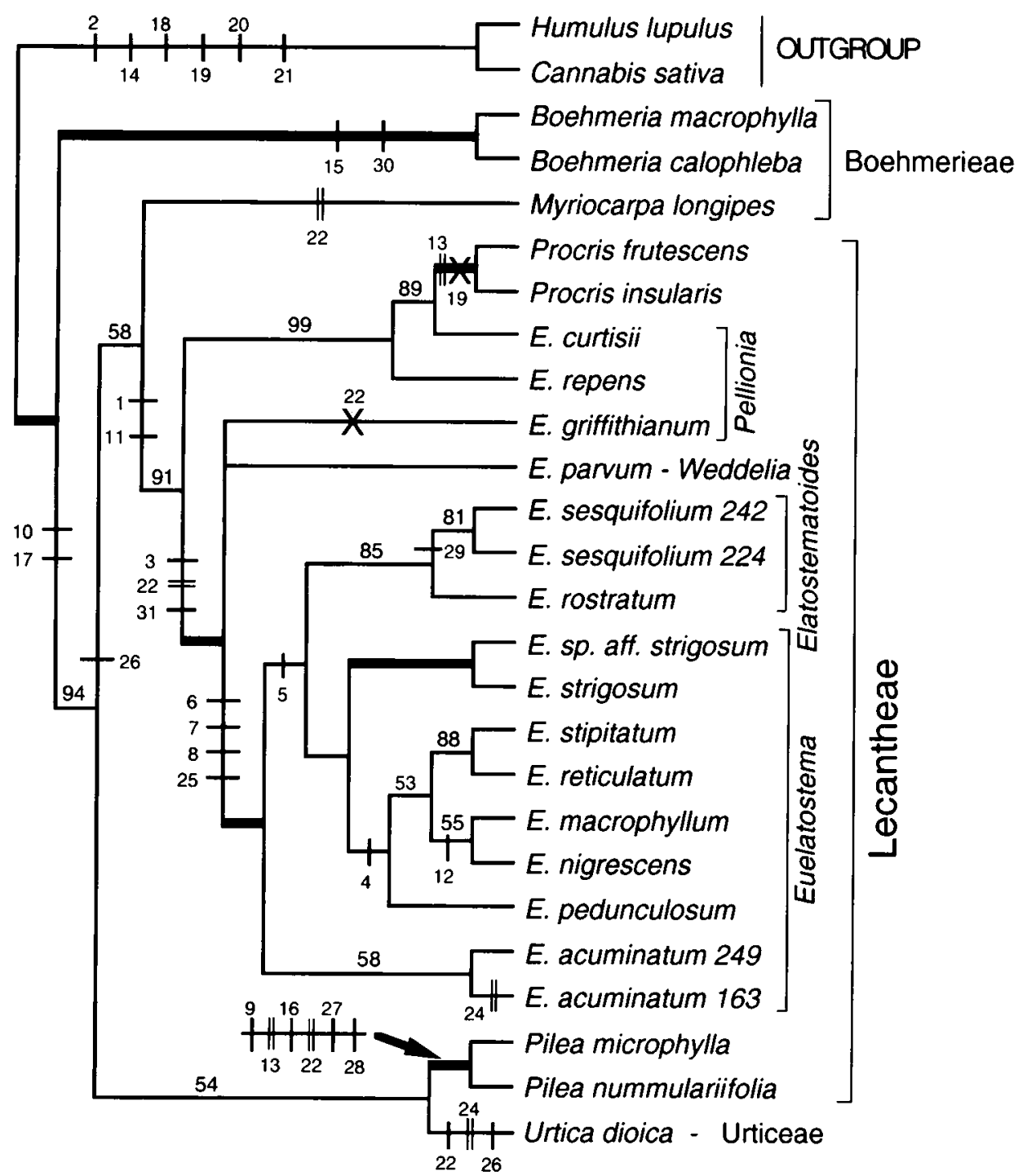

Fig. 3. Strict consensus of two equally parsimonious trees of 663 steps found from heuristic search of the $t r n$ data set; $\mathrm{CI}=0.733$ excluding uninformative characters; $\mathrm{RI}=0.846 ; \mathrm{RC}=0.688$. Thick branches received $100 \%$ jackknife support; other values $>50 \%$ shown above the branches. Distributions of 31 scored indels have been mapped on the tree; single bar indicates unique origin; double bar indicates homoplasy; $X$ indicates reversal. E., Elatostema. 
support. In both Figures 1 and 3, the Lecantheae (Elatostema, Pilea and Procris) and Boehmerieae (Boehmeria and Myriocarpa) are paraphyletic. Constraint analyses of the trn data set revealed that an extra 15 steps are required over and above the most parsimonious tree to render the Lecantheae monophyletic, and a total of 31 extra steps are needed to make both tribes monophyletic. It can be concluded, therefore, that there is considerable strength in these data to reject the present tribal arrangement of these genera. The grouping of Pilea with Urtica, however, which is apparent in both analyses, may well be an artefact of the low taxon sampling. It is only weakly supported on the trn data (54\%), and both genera are on very long terminal branches (data not presented here).

The monophyly of Boehmeria, Pilea and Procris received high levels of jackknife support in all the analyses where more than one species was included, but the more extensive sampling of Elatostema in the trn analysis revealed it to be paraphyletic with respect to Procris. Support for the grouping of Elatostema curtisii and E. repens with Procris is very robust (99\%).

Support for the 'Elatostema-Procris' clade is high in all three data sets. The placement of the latter genus within Elatostema in the trn analysis, supports the broader concept of Elatostema adopted by Hallier (1896) and Winkler (1922). An alternative conclusion is that the current circumscription of Procris should be extended such that this group could be maintained as a separate genus. It is clear from Figure 3 that even as a subgenus, the limits of Procris need to be extended to include further species (eg. Elatostema curtisii and E. repens) currently assigned to Elatostema. The robust grouping $(100 \%)$ of E. griffithianum with species of subgenera Elatostema, Elatostematoides and Weddelia indicates that the morphological basis for the recognition of subgenus Pellionia (Schröter \& Winkler 1935 \& 1936) (or as a distinct genus - as classified by Weddell 1856, Robinson 1910, Friis 1989), at least, is not supported by the molecular data. Beaman (2000, 2001), using morphological features, also concluded that subgenus Pellionia was not distinct from the other subgenera. Furthermore, the current circumscriptions of the first three subgenera are also not supported by molecular data.

Overwhelmingly, the distributions of indels are congruent with the estimate of the phylogeny obtained primarily from the substitution data, and they can be seen to support many of the clades: e.g. both species of Pilea are characterised by four unique indels $(9,16,27 \& 28)$ and another two $(13 \& 22)$ that also arise on other lineages (Fig. 3). All six of the informative indels in atpß- $r b c \mathrm{~L}$ required only a single origin when their distributions were mapped on the strict consensus tree (Fig. 2), and only three of the 31 informative indels $(13,22 \& 24)$ in the trn region required more than one origin (Fig. 3). Two of these (indels 13 and 24) involved the gain or loss of a single base pair from non-coding regions. Multiple origins of such indels in intergenic spacers have been frequently observed (e.g. Golenberg et al. 1993, Lowrey et al. 2001). Indels 19 and 22 required reversals (Fig. 3), but resolution of the trichotomy so that Elatostema parvum diverged after E. griffithianum would remove the need for the reversal in the latter case. The outgroup (Cannabaceae) differ from the ingroup by six indels $(2,14$, $18,19,20 \& 21$ ), although indel 19 (a 6 bp insertion) has been subsequently lost in both species of Procris. This case of homoplasy (reversal or parallel origins) is interesting, since the indel is not a duplication of adjacent sequence, a type that has been observed to be common in spacer regions (Golenberg et al. 1993, Kelchner \& Clark 1997). It is possible that secondary structure of the trnL-F spacer region may be responsible for the loss of the inserted region in its entirety, although there was no evidence of complementary segments of sequence on either side of the insertion which might promote the formation of a loop (Kelchner \& Wendel 1996). 
Sequences for all three regions could be confidently aligned across the family. Both the trn and $r b c \mathrm{~L}$ data sets could be rooted outside the family, and yielded good resolution of generic relationships. The latter, however, provided only low levels of variability: e.g. the uncorrected pairwise sequence divergence between Elatostema acuminatum and E. paroum was only $0.7 \%$. As a result, jackknife support for clades was often relatively low even in this small taxon set. It is concluded that this region of the chloroplast genome is insufficiently variable to provide robust resolution of relationships within the genus. The trn region provided the highest proportion of variable characters: the uncorrected pairwise divergence between E. acuminatum and E. paroum was $5.1 \%$. Hence, this is the most promising of the three regions trialled here for resolving interspecific relationships within Elatostema. Even within this region, however, relationships were not fully resolved in a very limited taxon sample (Fig. 3), and pairwise divergences between species are frequently very low: e.g. $0.02 \%$ for $E$. reticulatum cf. E. stipitatum, $0.04 \%$ for E. rostratum cf. E. sesquifolium. It therefore appears that robust resolution of species relationships within the genus will require a more variable region of DNA. The nuclear encoded intergenic transcribed spacer region of the rDNA is currently being investigated for this purpose.

Finally, the recognition of the misidentification of two of the outgroup sequences highlights the caution that must be exercised about the authenticity of sequences lodged in GenBank and the importance of including voucher details when sequences are lodged - in this case no voucher was provided by either author.

\section{Conclusion}

Phylogenetic analyses of the Urticales, based on chloroplast DNA sequences, provided support for the monophyly of the Urticaceae, but not for the tribe Lecantheae. However, the apparent paraphyletic nature of the tribe may be an artefact of low taxon sampling, particularly in the Urticeae. Although Boehmeria is monophyletic, the Boehmerieae is polyphyletic, with the tribal position of Myriocarpa uncertain. The genus Elatostema, a member of the Lecantheae, has been shown to be paraphyletic, having the segregate genus Procris embedded within it. The preliminary analyses of infrageneric relationships within Elatostema do not support the recognition of the subgenus Pellionia.

\section{Acknowledgments}

We thank Esti Ariyanti (Kebun Raya Purwodadi, Indonesia) for her field assistance and companionship in Sumatera (Indonesia). Dedy Darnaedi (Director) and staff of Kebun Raya Bogor (Indonesia) provided considerable logistical field support for our (JTH \& BJC) field work in Sumatera and accommodation for BJC while in Bogor. Frank Zich (CANB - formerly Kebun Raya Indonesia) for field assistance in West Java and Bali. We thank Adjun, Nanang Suryana and Rustandi (all Kebun Raya Cibodas) for their field assistance in Java and skilful cultivation of plants, as well as Ruspandi (Kebun Raya Bogor) for assisting with initial identification. Margaret Heslewood (NSW-formerly University of NSW, Kensington) and Andrew Perkins (NSW) generously provided technical assistance and advice on DNA laboratory techniques. We thank the Directors and staff of the following herbaria for making collections available as loans and donations, namely A, BRI, CANB, E, K, L, LAE, MEL, MO and NY. One of us (JTH) is supported by an AusAID post-graduate scholarship. This support is gratefully acknowledged. 


\section{References}

Angiosperm Phylogeny Group (1998) An ordinal classification for the families of flowering plants. Annals of the Missouri Botanical Garden 85: 531-553.

Beaman, R.S. (2000) Phylogeny and biogeography of Elatostema (Urticaceae) from Mount Kinabalu, Sabah, Malaysia (unpubl. Ph.D. dissertation: Univ. Florida, USA).

Beaman, R.S. (2001) Phylogeny and biogeography of Elatostema (Urticaceae) from Mount Kinabalu. Sabah Parks Nature Journal 4: 71-93.

Berg, C.C. (1978) Cecropiaceae. A new family of the Urticales. Taxon 27: 39-44.

Briggs, B.G., A.D. Marchant, S. Gilmore \& C.L. Porter, (2000). A molecular phylogeny of Restionaceae and allies. Monocots: Systematics and Evolution. K. L. Wilson \& D. A. Morrison (Eds). (CSIRO: Melbourne).

Chase, M.W., D.E. Soltis, R. G. Olmstead, D. Morgan, D.H. Les, B.D. Mishler, M.R. Duvall, R.A. Price, H.G. Hills, Y. Qiu, K.A. Kron, J.H. Rettig, E. Conti, J.D. Palmer, J.R. Manhart, K.J. Sytsma, H.J. Michaels, W.J. Kress, K.G. Karol, W.D. Clark, M. Hedren, B.S. Gaut, R.K. Jansen, K. Kim, C.F. Wimpee, J.F. Smith, G.R. Furnier, S.H. Strauss, Q. Xiang, G.M. Plunkett, P.S. Soltis, S.M. Swensen, S.E. Williams, P.A. Gadek, C.J. Quinn, L.E. Eguiarte, E. Golenberg, G.H. Learn, Jr., S.W. Graham, S.C.H. Barrett, S. Dayanandan \& V.A. Albert (1993) Phylogenetics of seed plants: an analysis of nucleotide sequences from the plastid gene $r b c \mathrm{~L}$. Annals of the Missouri Botanical Garden 80: 528-580.

Crayn, D.M. \& C.J. Quinn (2000) The evolution of the atpß-rbcL intergenic spacer in the epacrids (Ericales) and its systematic and evolutionary implications. Molecular Phylogenetics and Evolution 16: $238-252$.

Cronquist, A. (1981) An integrated system of classification of flowering plants. (Columbia University Press: New York).

Dahlgren, G. (1989) The last Dahlgrenogram, system of classification of the dicotyledons. Pp. 249-260 in plant taxonomy, phytogeography, and related subjects. Tan, K. (ed.). (Edinburgh University Press: Edinburgh).

Dickison, W. C. \& E. M. Sweitzer (1970) The morphology and relationship of Barbeya oleoides. American Journal of Botany 57: 468-476.

Friis, I. (1989) The Urticaceae: a systematic review. The Systematics Association Special Volume No. 40B: Evolution, systematics, and fossil history of the Hamamelidae. Volume 2: higher Hamamelida, pp. 285-308.

Friis, I. (1993) Urticaceae. Pp. 612-630 in K. Kubitzki, J.G. Rohwer \& V. Bittrich (eds). The families and genera of vascular plants II, flowering plants - dicotyledones. Magnoliid, hamamelid and caryophyllid families. (Springer-Verlag: Berlin).

Gaudichaud, C. (1830) Botanique, part 12. Voyage autour du monde ... execute sur les corvettes de S.M. l'Uranie et la Physiciene (L. de Freycinet, ed.), pp. 465-522, tt. 111-120. (Pilet-Aine: Paris).

Gilmore, S., P.H. Weston \& J.A. Thomson (1993) A simple, rapid, inexpensive and widely applicable technique for purifying plant DNA. Australian Systematic Botany 6: 139-148.

Golenberg, E.M., M.T. Clegg, M.L. Durbin, J. Doebley \& D.P.Ma (1993) Evolution of a noncoding region of the chloroplast genome. Molecular Phylogenetics and Evolution 2: 52-64.

Hallier, H. (1896) Neue und bemerkenswerte pflanzen aus dem malaiisch-papuanischen inselmeer. Annales du Jardin Botanique de Buitenzorg 13: 300-316.

Judd, W.S., C.S. Campbell, E.A. Kellogg \& P.F. Stevens (1999) Plant systematics: A phylogenetic approach. (Sinauer Associates: Sunderland, Massachusetts).

Kelchner, S.A. \& L.G. Clark (1997) Molecular evolution and phylogenetic utility of the chloroplast rpl16 intron in Chusquea and the Bambusoideae (Poaceae). Molecular Phylogenetics and Evolution 8: 385-397.

Kelchner, S.A. \& J.F. Wendel (1996) Hairpins create minute inversions in non-coding regions of chloroplast DNA. Current Genetics 30: 295-262.

Lowrey T.K., C.J. Quinn, R.K. Taylor, R. Chan, R.T. Kimball, J.C. De Nardi (2001) Molecular and morphological reassessment of relationships within the Vittadinia group of Astereae (Asteraceae). American Journal of Botany 88: 1279-1289.

Maddison W.P. and Maddison D.R. (2001) MacClade, version 4.03. (Sinauer Associates: Sunderland, Massachusetts).

O'Brien, M.M., C.J. Quinn and P.G. Wilson (2000). Molecular systematics of the Leptospermum suballiance (Myrtaceae). Australian Journal of Botany 48: 621-628.

Robinson, C.B. (1910). Philippine Urticaceae. Philippines Journal of Science 5: 465-542. 
Schröter, H. \& H. Winkler (1935) Monographie der gattung Elatostema s. 1.: Allgemeiner teil. Repertorium specierum novarum regni vegetabilis LXXXIII, 1.

Schröter, H. \& H. Winkler (1936) Monographie der gattung Elatostema s. 1.: Spezieller teil. Repertorium specierum novarum regni vegetabilis LXXXIII, 2.

Soltis, D.E. \& R.K. Kuzoff (1995) Discordance between nuclear and chloroplast phylogenies in the Heuchera groups (Saxifragaceae). Evolution 49 (4): 727-742.

Soltis, D.E., P.S. Soltis, M.W. Chase, M.E. Mort, D.C. Albach, M. Zanis, V. Savolainen, W.H. Hahn, S.B. Hoot, M.F. Fay, M. Axtell, S.M. Swensen, L. M. Prince, W.J. Kress, K.C. Nixon \& J.S. Farris (2000) Angiosperm phylogeny inferred from $18 \mathrm{~S} \mathrm{rDNA}, r b c \mathrm{~L}$, and atpß sequences. Botanical Journal of the Linnean Society 133 (4): 381-461.

Swofford, D.L. (2002) PAUP*. Phylogenetic Analysis Using Parsimony (*and other methods). Version 4.0b10. (Sinauer Associates: Sunderland, Massachusetts).

Taberlet, P., L. Gielly, G. Pautou \& J. Bouvet (1991) Universal primers for the amplification of three non-coding regions of chloroplast DNA. Plant Molecular Biology 17: 1105-1109.

Takhtajan, A.L. (1997) Diversity and classification of flowering plants. (Columbia University Press: New York).

Thomson, J.A., P.H. Weston, \& M. K. Tan (1995) A molecular approach to tracing major lineages in Pteridium. Pp. 21-28 in R.T. Smith and J.A. Taylor (Eds). Bracken: an Environmental Issue. Special Publication Number 2. (International Bracken Group: Aberystwyth).

Thorne, R.F. (1992) Classification and geography of the flowering plants. Botanical Review 58: 225-348.

Weddell, H.A. (1854) Revue de la famille de Urticacées. Annales des Sciences Naturelles; Botanique, Serie 4 (1): 173-212.

Weddell, H.A. (1856) Monographie de la famille des Urticacées. Archives du Museum D'Histoire Naturelle.

Weddell, H.A. (1869) Urticaceae. Prodromus systematis naturalis regni vegetabilis (ed. A. De Candolle) 16 (1): 32-235. (Masson: Paris).

Winkler, H. (1922) Die Urticaceen Papuasiens. Beiträge zur flora von Papuasien 8: 501-608.

Appendix 1. List of voucher specimens for DNA extracts and GenBank numbers for sequences. (Classification of Urticaceae follows Friis 1989, 1993).

\section{Taxa}

CANNABACEAE

Cannabis sativa

Humulus lupulus

\section{MORACEAE}

"Dorstenia psilurus"

Ficus pretoriae

Morus alba

"M. alba"

M. rubra

ROSACEAE

Prunus persica

ULMACEAE

Celtis sinensis

URTICAEAE

Boehmerieae

Boehmeria biloba

B. calophleba

B. macrophylla

B. nivea

Myriocarpa longipes

\section{Voucher No.}

rbcL

AJ390068

atpB-rbcL

trn region

(a)

(1)

AJ390066

AJ390067

D86319

L01933

U06812

AF206813

D86309

AJ390069

Hadiah $393 \quad$ AY208700

Hadiah $394 \quad$ AY208701

AJ235801

Hadiah 395
AY208705

\author{
AJ390367 \\ AB033889 - intron \\ AB033890 — spacer
}


Appendix 1. cont.

\begin{tabular}{|c|c|c|c|c|}
\hline Taxa & Voucher No. & $r b c L$ & atpB-rbcL & trn region \\
\hline \multicolumn{5}{|l|}{ Lecantheae } \\
\hline \multicolumn{5}{|c|}{ Elatostema-Elatostemoides } \\
\hline E. rostratum & Hadiah 144 & & & AY208743 \\
\hline E. rostratum group & Hadiah 141 & & AY208714 & \\
\hline E. sesquifolium & Hadiah 224 & & & AY208742 \\
\hline E. sesquifolium & Hadiah 242 & & & AY208741 \\
\hline \multicolumn{5}{|l|}{ Elatostema - Elatostema } \\
\hline E. acuminatum & Hadiah 163 & & AY208710 & AY208745 \\
\hline E. acuminatum & Hadiah 249 & AY208702 & AY208711 & AY208744 \\
\hline E. macrophyllum & Hadiah 245 & & & AY208739 \\
\hline E. nigrescens & Hadiah 256 & & & AY208740 \\
\hline E. pedunculosum & Hadiah 312 & & & AY208738 \\
\hline E. reticulatum & Perkins 00/01 & & AY208708 & AY208737 \\
\hline E. stipitatum & Perkins 00/02 & & AY208709 & AY208736 \\
\hline E. strigosum & Hadiah 159 & & AY208717 & AY208735 \\
\hline E. sp. aff. strigosum & Hadiah 178 & & AY208715 & AY208734 \\
\hline E. sp. aff. strigosum & Hadiah 207 & & AY208716 & \\
\hline E. sp. aff. velutinicaule & Hadiah 183 & & AY208713 & \\
\hline \multicolumn{5}{|l|}{ Elatostema-Pellionia } \\
\hline E. curtisii & Hadiah 427 & & & AY208731 \\
\hline E. griffithianum & Hadiah 351 & & & AY208732 \\
\hline E. repens & Hadiah 445 & & & AY208730 \\
\hline \multicolumn{5}{|l|}{ Elatostema - Weddelia } \\
\hline E. parvum & Hadiah 154 & AY208703 & AY208712 & AY208733 \\
\hline Pilea microphylla & Hadiah 398 & & & AY208726 \\
\hline P. nummulariifolia & Hadiah 389 & & AY208721 & AY208727 \\
\hline P. pumila & & AF206811 & & \\
\hline Procris frutescens & Hadiah 149 & AY208704 & AY208718 & AY208728 \\
\hline P. insularis & Hadiah 390 & AY208706 & AY208719 & AY208729 \\
\hline \multicolumn{5}{|l|}{ Urticeae } \\
\hline Urtica dioica & Hadiah 391 & AY208707 & & AY208725 \\
\hline
\end{tabular}

Appendix 2. Primers use for PCR (P) and sequencing (S); F, forward; $R$, reverse.

\begin{tabular}{l|lll}
\multicolumn{1}{l}{ Region } & Use & Primer & Reference or sequence \\
\hline \multirow{4}{*}{$r b c L$} & P/F & rbCL 1 & GGGATTTATGTCACCACAAACAGA - P. Gadek, unpubl. \\
& P/R & $r b C L 2$ & GATCTCCTTCCATACTTCACAAGC - P. Gadek, unpubl. \\
& S/F & 861 & TGGACCACTGTTTGGACCGA - P. Gadek, unpubl. \\
& S/F & 381 & GCAGTTATTGACAGACAAAGAAATCATGGT - P. Gadek, unpubl. \\
& S/R & 497 & ACCATGATTCTTCTGCCTATCAATAACTGC - P. Gadek, unpubl. \\
\hline \multirow{5}{*}{ atpB-rbCL } & P/F & 377 & Crayn \& Quinn (2000) \\
& P/R & 520 & O'Brien et al. (2000) \\
& S/F & 2603 & Crayn \& Quinn (2000) \\
& S/R & 2604 & Crayn \& Quinn (2000) \\
& S/R & 2607 & Crayn \& Quinn (2000) \\
\hline \multirow{5}{*}{ trnL-F } & PS/F & B49317 & Taberlet et al. (1991) \\
& PS/R & CalTabF & GTCCTCTGCTCTACCAACTG - A. Perkins, unpubl. \\
& PS/R & A50272 & Taberlet et al. (1991) \\
& S/F & AdTabB2 & Briggs et al. (2000) \\
& S/R & A49855 & Taberlet et al. (1991) \\
\hline
\end{tabular}

